\title{
Geophysical identification of voids and loosened zones in the shallow subsurface of post-mining areas
}

\author{
Zenon Pilecki* \\ Mineral and Energy Economy Research Institute of the Polish Academy of Sciences, Cracow, Poland
}

\begin{abstract}
The shallow historic exploitation of $\mathrm{Zn}-\mathrm{Pb} / \mathrm{Fe}$ ore deposits as well as hard coal has generated many discontinuous deformations on the terrain surface in the Upper Silesian Coal Basin/Poland. Discontinuous deformations occur in different forms as sinkholes, synclines, cracks, faults or ditches. The basic cause of their occurrence is the presence of void and loosened zones in the shallow subsurface. If the appropriate conditions arise, the sinkhole process begins to move upwards and may cause a discontinuous deformation on the terrain surface. Typically, geophysical methods are used for void and loosened zone identification. The most effective methods are gravimetric, seismic, electric resistivity and ground penetrating radar (GPR). Geophysical testing, requires distinct changes in the physical properties in the rock mass. The identified geophysical anomalies should be verified by control borehole and borehole tests to confirm the presence of the void and loosened zones in the rock mass. The results of control drilling and borehole tests determine the need to apply treatment works. In order to assess the threat of the occurrence of discontinuous deformations in the areas of historical shallow mining in Upper Silesia, a classification system based on geophysical tests has also been developed.
\end{abstract}

Keywords: shallow exploitation, voids and loosened zones, discontinuous deformations, geophysical methods

\section{Introduction}

Shallow subsurface voids and loosened zones of mining origin may be the cause of the activation of sinkhole processes [1-11] (Fig. 1). In unfavorable geological and mining conditions, sinkhole processes may appear on the terrain surface creating various kinds of discontinuous deformations. In the conditions of shallow exploitation of deposits of $\mathrm{Zn}-\mathrm{Pb} / \mathrm{Fe}$ ores and hard coal in the northern part of the Upper Silesian Coal Basin (USCB), these are most often the forms of the sinkholes (Fig. 2) [9]. In general, most sinkholes have dimensions of up to $3.0 \mathrm{~m}$. The arithmetic mean of a sinkhole surface length amounts to $5.0 \mathrm{~m}$, the minimum is $0.5 \mathrm{~m}$ and the maximum $17 \mathrm{~m}$. Also, the mean surface width amounts to $3.6 \mathrm{~m}$, the minimum width is $0.3 \mathrm{~m}$ and the maximum width $12 \mathrm{~m}$ [9].

\footnotetext{
*Corresponding author: pilecki@meeri.pl
} 

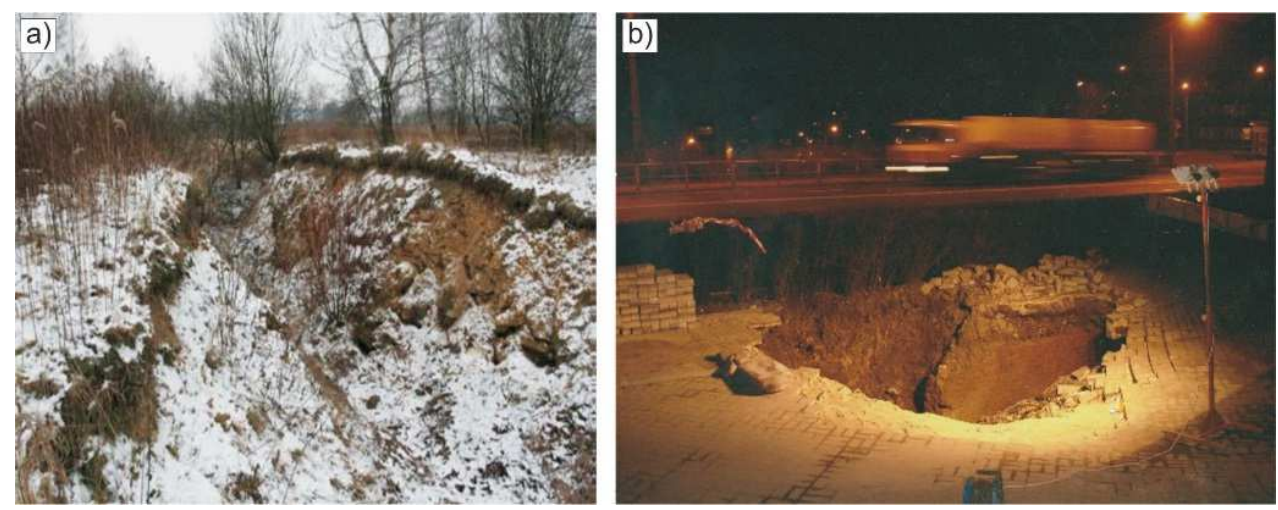

Fig. 1. (a) A ditch on post mining terrain of shallow $\mathrm{Zn}-\mathrm{Pb}$ exploitation near Bytom town (phot. Z. Pilecki); (b) A cuboid sinkhole over an old shaft near Chorzów town (phot. M. Rotkegel).

a)

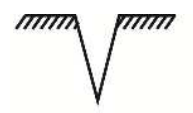

[1]

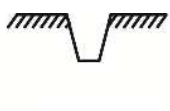

[2]

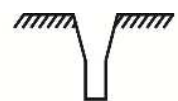

[3]

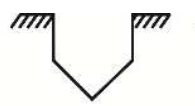

[4]

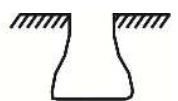

[5]

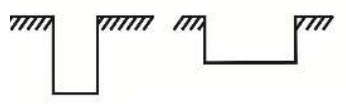

[6]
[7]

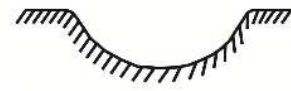

[8]

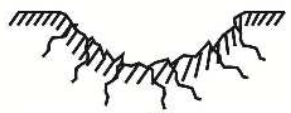

[9]

b)

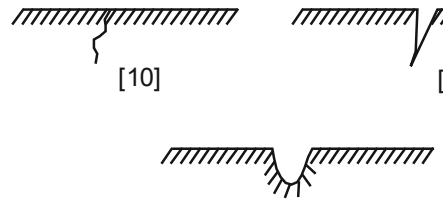

[13]

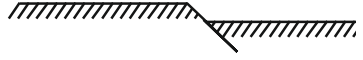

[12]

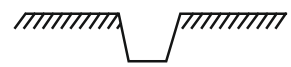

[14]

Fig. 2. Kinds of discontinuous deformations on the terrain surface in the vertical section observed in the area of Upper Silesia Coal Basin - (a) surface and (b) linear deformations (on the basis [1, 6]); [1] - conical sinkhole, [2] - truncated sinkhole, [3] - conical-cylindrical sinkhole, [4] - cylindrical conical sinkhole, [5] - bell sinkhole, [6] - cylindrical sinkhole, [7] - cuboid sinkhole, [8] - continuous syncline, [9] - discontinuous syncline, [10] - crack, [11] - fissure, [12] - fault deformation, [13] ditch, [14] - smoothed ditch.

\section{Model of the formation sinkhole process}

The model of the sinkhole formation process induced by shallow exploitation of various deposits has been discussed, among others, by [2-7, 10-11]. The identification of voids and loosened zones from the point of view of geophysical investigations have been undertaken, among others, by $[6,8-9,12-20]$.

In a very general sense, the sinkhole formation process responsible for propagating the void towards the terrain surface may be presented using the "pressure arch" theory [21]. The model assumes that the void has the shape of an ellipse with a height of $2 \mathrm{c}$ and a width of $2 \mathrm{a}$.

According to the theory of elasticity, radial stresses $\sigma_{\mathrm{r}}$ on the outline of the void are described by the following dependencies [21]: 
a) in the roof and floor of the void

$$
\sigma_{r}^{v}=\sigma_{x}^{0}\left(1+2 \frac{c}{a}\right)-\sigma_{z}^{0}
$$

b) in the sidewalls of the void

$$
\sigma_{r}^{h}=\sigma_{z}^{0}\left(1+2 \frac{a}{c}\right)-\sigma_{x}^{0}
$$

where:

$\sigma_{z}^{0}$ and $\sigma_{x}^{0}$ are the primary stresses in the vertical and horizontal direction respectively in the rock mass.

From dependencies (1) and (2) it follows that the ratio of the void height to its width is related to the distribution of stress at the border with the rock mass :

$$
\frac{1}{2}\left(\frac{\sigma_{z}^{0}}{\sigma_{x}^{0}}-1\right)=\frac{c}{a}
$$

The ratio $\sigma_{z}^{0} / \sigma_{x}^{0}$ increases from a value of 1 for hydrostatic conditions at large depths, to large values for voids in very shallow locations. If the void is located closer to the terrain surface, its shape should be more elongated in the vertical direction to maintain the force equilibrium at the border with the surrounding medium. Therefore, the different shape of the void and the unbalance of the relevant forces may cause the development of gravitional shear forces leading to the fracturing of rock mass. The fracture zone will grow until a new forces equilibrium is established related to the new shape of the void. The image of the void and its surroundings may be presented as a configuration of four zones (Fig. 3) [5, 6]:

(I) - void, often filled with water, containing rock fragments and soil material deposited in the floor;

(II) - intense fractures, mainly in the roof and sidewalls of the void, with the density of the fractures decreasing with greater distance from the void boundary,

(III) - fractures surrounding the void, to the border with the undisturbed rock mass,

(IV) - undisturbed rock mass by the propagating void.

A geophysical image of void with the surrounding fractured rock mass can be simplified to two zones, the most important from the point of view of geophysical identification are as follows:

- central zone - void with rock fragments and soil material deposited on its floor and possibly filled with water, characterized by a very high contrast of physical properties in comparison with the undisturbed rock mass.

- external zone - it is a fracture zone from the border of the void to the border with the undisturbed rock mass. The properties of this zone depend on the density of the fractures. In comparison to undisturbed rock mass, it is characterized by lower seismic wave velocity, greater anisotropy depending on the orientation of the fracture systems, increased electric resistance of the medium, lower volumetric density, or changes to electromagnetic parameters. This zone strengthens the anomalous effect of the central zone in the geophysical identification of the void. 


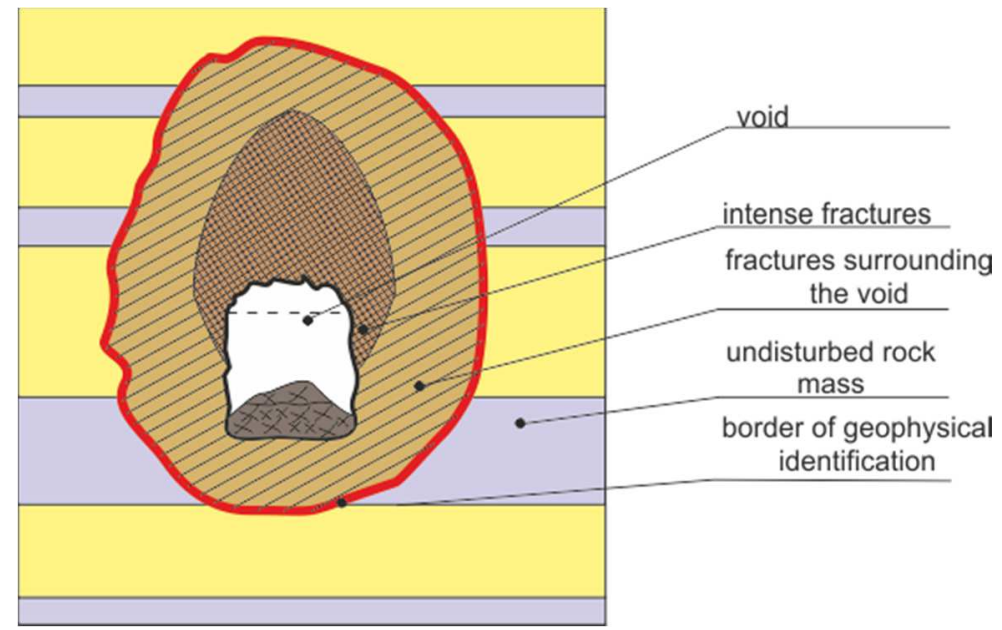

Fig. 3. Geophysical model of a void of mining origin [5].

Void propagation towards the terrain surface may be illustrated by numerical simulation, assuming that tensile stress resulting from the gravity force has the decisive influence on the growth of fractures in the void roof (Fig. 4).

a)

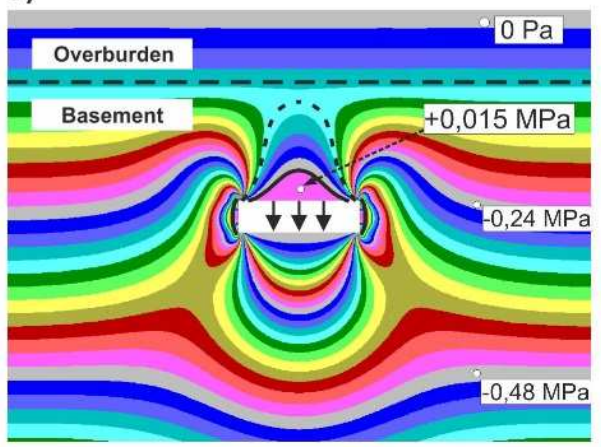

c)

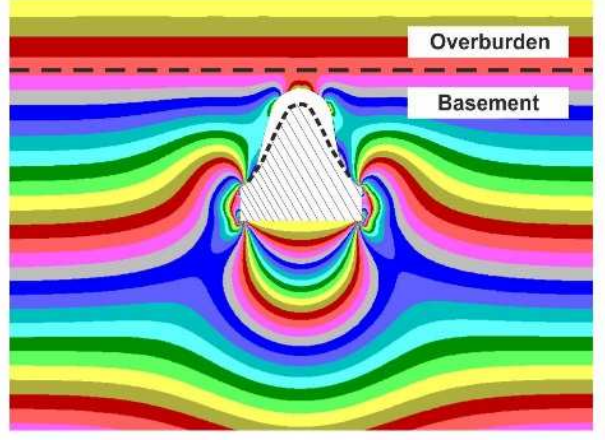

b)

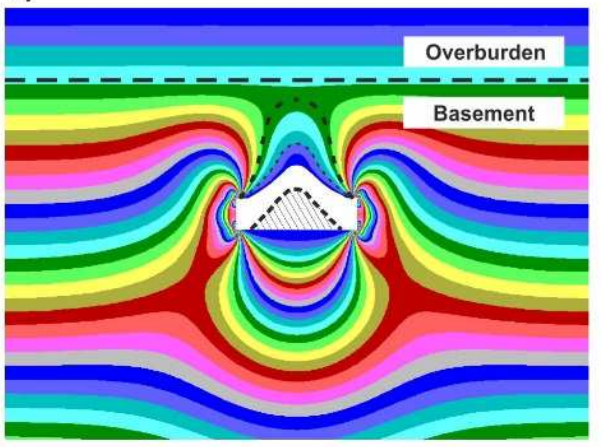

d)

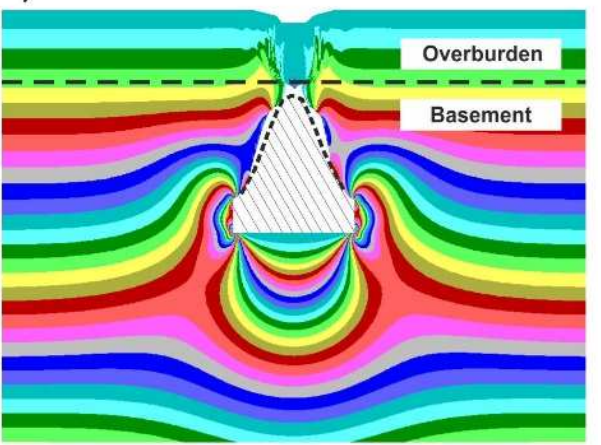

Fig. 4. (a) Redistribution of primary stress and the development of the fracture zone in the roof of the void; (b) the collapsing process of the roof of the void comprising a tensile stress zone; (c) secondary collapsing of the roof of the void; (d) reaching the border with loose overburden formations and the occurrence of a sinkhole on the terrain surface [11]. 


\section{Methodology of the identification of voids and loosened zones in areas of shallow exploitation using geophysical methods}

The geophysical identification of voids and loosened zones, referred to as weak zones, requires distinct changes in the physical properties of the medium $[5,6]$. These changes are resulted from a comparison of the properties of the void zone together with the fracture zone to the properties of the surrounding, undisturbed medium. The external boundary of this system is not clearly determinable, since it is most often of a transitional nature related to a change in the fracture density. It should also be emphasized that the geophysical image of weak zones changes over time and depends on the impact of many factors activating the sinkhole process in the medium.

For the geophysical identification of weak zones in USCB conditions it was assumed that the basic research method is microgravimetry. The results of gravimetric tests were correlated with the results of seismic measurements or in case of further ambiguity with the results of the GPR or resistance method. In particular, the proposed methodology includes the following stages [9]:

Stage I - determination of weak zones using the gravimetric method, seismic refraction profiling and mapping of mining terrain also using aerial, satellite or drone images. Recently, terrain laser scanning has proven to be useful for mapping terrain prone to discontinous deformation [20].

Stage II - verification of gravimetric and seismic anomalies with other seismic techniques, or using a georadar or electric resistance method. The selection of the method should result from the measurement conditions - in the areas of occurrence of metal ore deposits the use of the electric resistance method is not recommended.

Stage III - verification of geophysical anomalies by means of cored control drilling along with recognition using a borehole camera, or borehole georadar, or other method.

Stage IV - in the case of liquidation of the weak zone, for instance by backfilling, the quality of the filling should be checked with one of the geophysical methods used at the stage of anomaly identification.

The use of the gravimetric method as the basic technique results from the fact that the volumetric density is a clear contrasting physical parameter in the tested basement disturbed by shallow exploitation. Figure 5 shows an example of such gravity surveys supplemented by seismic surveys. The aim of the seismic refraction profiling presented in Figure 5 was to determine the course of the boundary between overburden and basement, and the velocity changes of the refraction wave in the basement. Seismic refraction measurements were supported by the vertical profiling of S-wave velocity changes.

The GPR or electric resistance method are used as complementary methods depending on the measurement conditions. These methods use other properties of the medium, which may allow for a more reliable image of the weak zones in rock mass.

The verification of the results of geophysical identification usually consist of making a control borehole along with penetration by a camera or a borehole georadar. The results of drilling and borehole testing allow for a decision to be made about applying treatment works, and protecting the terrain surface from deformation. 

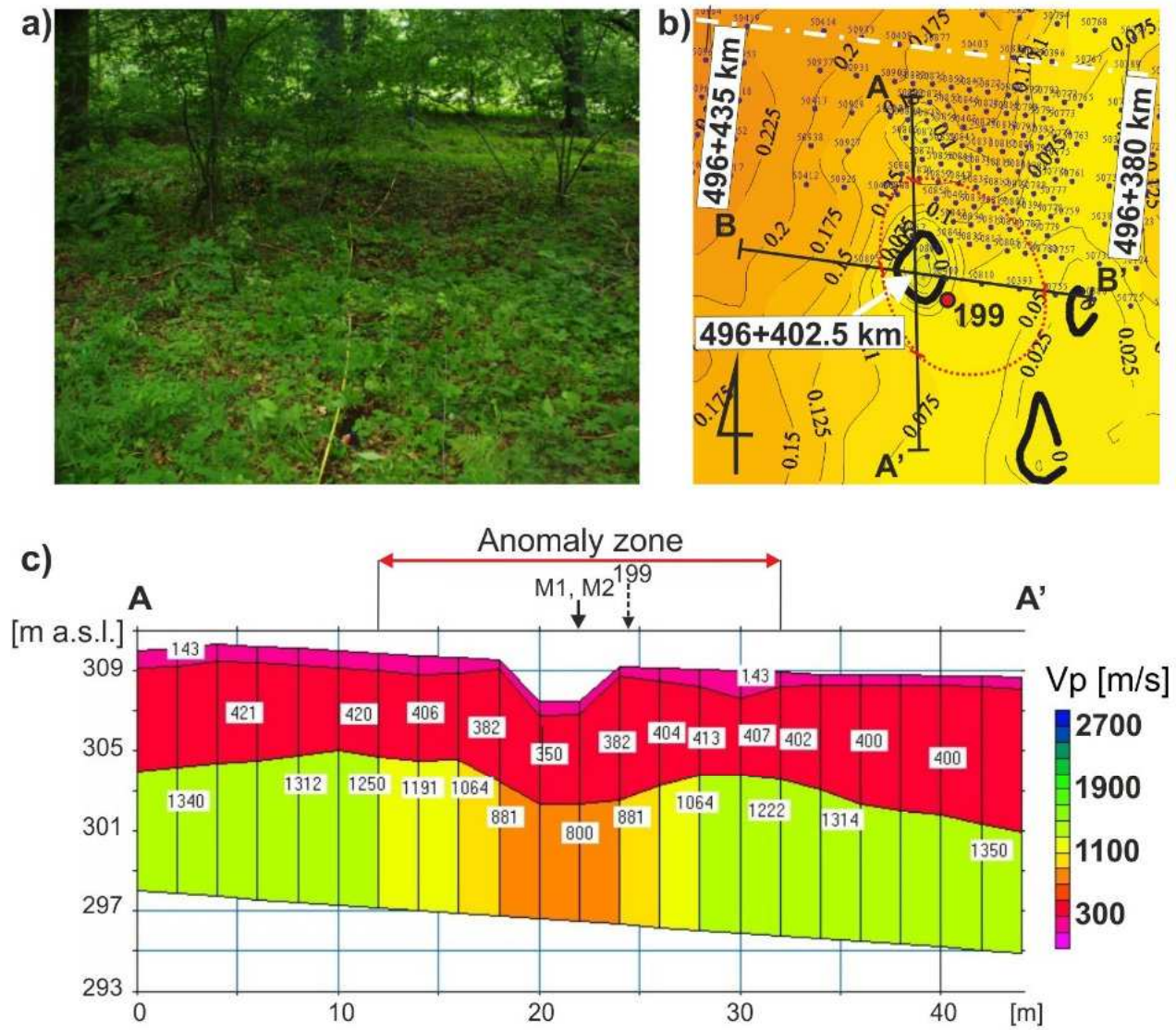

d)
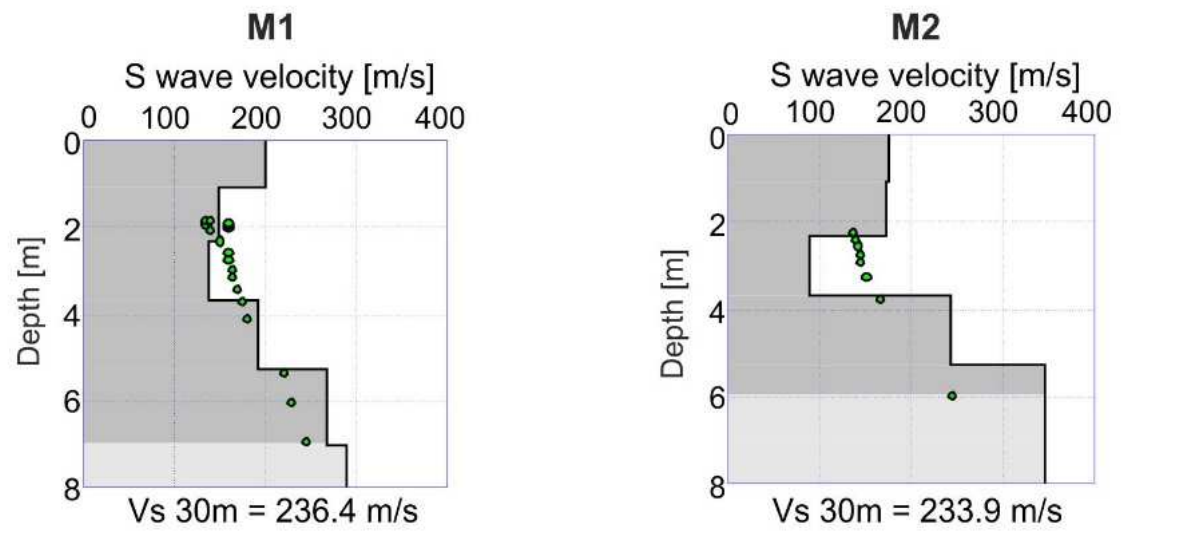

Fig. 5. (a) View of the sinkhole above the liquidated shaft 796 in an area of historical, shallow exploitation of zinc and lead ores deposit near Piekary Śl.; (b) a gravimetric map with an anomaly marked (source: J. Madej with the team) and the location of seismic profiles; (c) refractive crosssection with a visible seismic anomaly; (d) vertical profiling of the $\mathrm{S}$ wave velocity at the site of the seismic anomaly [6]. 


\section{Classification of the threat assessment of the occurrence of discontinuous deformations on the terrain surface}

The assessment of the threat of the occurrence of discontinuous deformations in the postmining areas in Upper Silesia based on analytical methods is very difficult. This is mainly due to the unknown degree of rock mass distruction folowing the shallow exploitation of metal ore deposits or hard coal seams and often deep exploitation of coal seams. Under these conditions, information concerning the sinkhole threat is provided by geophysical identification. In the case of areas designated for building, classifications based on the likelihood of discontinuous deformations are used. Table 1 presents a modified classification of Pilecki and Kotyrba [22] to assess the likelihood of discontinuous deformations occurring in the areas of shallow exploitation of metal ore deposits or hard coal seams in USCB. The classification assumes that the probability of discontinuous deformations occurrence in conditions of overburden of loose soils with a thickness above $5 \mathrm{~m}$, is low due to the selffilling of excavations. In rock mass disturbed by exploitation, with the increase in weak zone depth, the probability of the occurrence of discontinous deformations on the terrain surface clearly decreases.

Table 1. Classification of the assessment of discontinuous deformation occurrence with the use of geophysical surveys in conditions of shallow exploitation of metal ore deposits and hard coal seams in the USCB [9].

\begin{tabular}{|c|c|}
\hline $\begin{array}{c}\text { Threat } \\
\text { category }\end{array}$ & Threat criteria \\
\hline \multirow{7}{*}{$\begin{array}{l}\text { A } \\
\text { Negligible } \\
\text { threat }^{1}\end{array}$} & no clear geophysical anomalies \\
\hline & no discontinuous deformations and other terrain surface deformations \\
\hline & $\begin{array}{l}\text { a possible shallow exploitation of metal ore (or coal seams) deposits at a depth } \\
\text { greater than } 30 \mathrm{~m} \text {, thickness of roof rocks at least five times greater than the } \\
\text { height of excavations, or the presence of excavations at a depth greater than } 30 \mathrm{~m}\end{array}$ \\
\hline & no excavations connected to the terrain surface \\
\hline & the mining area could be treated \\
\hline & no outcrops of faults at a depth less than $15 \mathrm{~m}$ \\
\hline & $\begin{array}{l}\text { thickness of overburden of loose soils greater than } 5 \mathrm{~m} \text {, or stable level of water in } \\
\text { the soil }\end{array}$ \\
\hline \multirow{6}{*}{$\begin{array}{c}\text { B } \\
\text { Small } \\
\text { threat }^{1}\end{array}$} & weak geophysical anomaly determined by at least one method \\
\hline & $\begin{array}{l}\text { no discontinuous deformations and other deformations of the terrain surface, or } \\
\text { the mining area treated and documentation of the liquidation of excavations is } \\
\text { available }\end{array}$ \\
\hline & $\begin{array}{l}\text { shallow exploitation of metal ore (or coal seams) deposits at a depth of more than } \\
20 \mathrm{~m} \text {, thickness of roof rocks at least five times greater than the height of } \\
\text { excavations, or exploitation of iron ore, or excavations at a depth greater than } \\
20 \mathrm{~m}\end{array}$ \\
\hline & thickness of overburden of loose soils greater than $5 \mathrm{~m}$ \\
\hline & no stable water level in the soil \\
\hline & outcrops of faults at a depth greater than $5 \mathrm{~m}$ \\
\hline \multirow{4}{*}{$\begin{array}{c}\text { C } \\
\text { Medium } \\
\text { threat }^{2}\end{array}$} & a clear geophysical anomaly determined by at least one method \\
\hline & $\begin{array}{l}\text { symptoms indicating a single discontinuous deformation of the terrain surface or } \\
\text { documented, liquidated discontinuous deformation }\end{array}$ \\
\hline & $\begin{array}{l}\text { the exploitation of ore deposits (or coal seams) at a depth greater than } 20 \mathrm{~m} \text {, the } \\
\text { thickness of the overlying rocks is between three and five times the height of the } \\
\text { excavations, or the presence of excavations at a depth greater than } 30 \mathrm{~m} \text {, or the } \\
\text { excavations having a connection to the terrain surface with documented proof of } \\
\text { their liquidation }\end{array}$ \\
\hline & $\begin{array}{l}\text { thickness of overburden of loose soil less than } 5 \mathrm{~m} \text {, lack of water or local water } \\
\text { occurrence in the loose soil }\end{array}$ \\
\hline
\end{tabular}




\begin{tabular}{|c|c|}
\hline & outcrops of faults at a depth less than $5 \mathrm{~m}$ \\
\hline \multirow{6}{*}{$\begin{array}{l}\text { D } \\
\text { Large } \\
\text { threat }^{2}\end{array}$} & a strong geophysical anomaly determined by at least two methods \\
\hline & $\begin{array}{l}\text { occurrence of discontinuous deformations in the past or clear symptoms } \\
\text { indicating numerous deformations of the discontinuous terrain surface }\end{array}$ \\
\hline & $\begin{array}{l}\text { shallow exploitation of metal ore (or coal seam) deposits at a depth less than } 20 \\
\mathrm{~m} \text {, and the thickness of the overlying rock layers less than three times the height } \\
\text { of excavations }\end{array}$ \\
\hline & $\begin{array}{c}\text { shallow exploitation of metal ore (or coal seam) deposits at a depth less than } 20 \\
\mathrm{~m} \text {, and the thickness of the overburden of loose soil less than } 5 \mathrm{~m}\end{array}$ \\
\hline & $\begin{array}{c}\text { the presence of excavations liqudated without documentation having a } \\
\text { connection with the terrain surface, or the presence of excavations of unknown } \\
\text { liquidation at a depth of less than } 20 \mathrm{~m}\end{array}$ \\
\hline & conducted mining works below shallow excavations \\
\hline \multirow{3}{*}{$\begin{array}{c}E \\
\text { Very large } \\
\text { threat }^{1}\end{array}$} & a strong geophysical anomaly determined by at least two methods \\
\hline & $\begin{array}{l}\text { occurrence of discontinuous deformations in the past or clear symptoms } \\
\text { indicating numerous discontinuous deformations of the terrain surface }\end{array}$ \\
\hline & $\begin{array}{l}\text { shallow exploitation of metal ore (or coal seam) deposits, or the occurrence of } \\
\text { excavations at a depth less than } 30 \mathrm{~m}\end{array}$ \\
\hline
\end{tabular}

\section{Summary}

Discontinuous deformations on the mining and post-mining terrain are most often the result of the presence of voids and loosened zones at shallow depths created as a result of shallow exploitation. If the appropriate conditions arise, the sinkhole process begins to move upwards and may cause a discontinuous deformation on the terrain surface. The dynamics of this process depends on local conditions. Goszcz [4] formulated the basic criterion to assess the discontinuous deformations threat: a post-mining void may cause a discontinuous deformation on the terrain surface, if the amount of rock material filling in this void does not cause self-filling as it moves towards the terrain surface.

Changes in physical properties associated with the void and the surrounding fracture zone increases the electrical resistance of the medium, and decreases the seismic waves velocity, reduces the volumetric density of the medium and changes the electromagnetic parameters giving an anomalous effect which is measurable using geophysical methods.

From previous experience in the areas of shallow deposits of hard coal and metal ores in USCB, it may be assumed that microgravimetric studies are the basic geophysical method. The results of gravimetric tests are most often correlated with the results of refraction seismic profiling as well as depending on the measurement conditions with the results of the GPR and electrical resistivity method. The identified geophysical anomalies should be verified by control borehole and borehole tests, e.g. the borehole georadar is used to confirm the presence of weak zones in the rock mass. The results of control drilling and borehole tests determine the need to apply treatment works.

In order to assess the probability of the occurrence of discontinuous deformations in the areas of historical shallow mining in Upper Silesia, a classification based on geophysical tests has been developed.

\section{References}

1. M. Chudek, W. Janusz, J. Zych, Studium dotyczące stanu rozpoznania tworzenia się $i$ prognozowania deformacji nieciaglych pod wplywem podziemnej eksploatacji złóż (Study on recognition of formation and forecasting of discontinuous deformations under 
the influence of underground exploitation). Zeszyty Naukowe Politechniki Śląskiej 141, Gliwice (1988) (in Polish)

2. F. G. Bell, Bulletin of the International Association of Engineering Geology 37, 91-98 (1988) doi: 10.1007/BF02590374

3. B. N. Whittaker, D. J. Reddish, Subsidence behaviour of rock structure, w: Comprehensive rock engineering - principles, practice and projects, J.A. Hudson ed., Pergamon Press, Oxford, New York (1993)

4. A. Goszcz, Powstawanie zapadlisk $i$ innych deformacji nieciaglych powierzchni na obszarach ptytkiej eksploatacji górniczej (Formation of sinkholes and other discontinuous deformations of terrain surfaces on areas of shallow exploitation). Mat. Konf.: Szkoła Eksploatacji Podziemnej, Wyd. CPPGSMiE PAN, Kraków, 119-137 (1996) (in Polish)

5. H. Marcak, Powstawanie zapadlisk $i$ innych form deformacji nieciagtych powierzchni spowodowanych wystepowaniem pustek (Formation of sinkholes and other forms of deformation of discontinuous surfaces caused by voids). Mat. Konf.: Warsztaty Górnicze, Wyd. IGSMiE PAN, Kraków, 71-84 (1999)

6. E. Popiołek, Z. Pilecki (eds.), Ocena przydatności do zabudowy terenów zagrożonych deformacjami nieciagtymi za pomoca metod geofizycznych (Assessment of areas threatened with discontinuous deformations for building suitability using geophysical methods) Wyd. IGSMiE PAN, Kraków (2005)

7. Z. Pilecki, A. Baranowski, Estimation of dimension of a regular-type sinkhole activated by abandoned shafts, Publications of the Institute of Geophysics, Polish Academy of Sciences M-29, 395, 271-279 (2006)

8. Z. Pilecki, Gospod. Surowcami Min. 25, 3, 319-331 (2009)

9. Z. Pilecki, Uzdatnienie podtoża autostrady A-1 na terenach pogórniczych płytkiej eksploatacji rud metali (Treatment of the A-1 motorway basement in post-mining areas of shallow mining of metal ore deposits) Studia, Rozprawy Monografie 184, Wyd. IGSMiE PAN, Kraków (2014)

10. P. Strzałkowski, Arch. Min. Sci. 60, 1, 63-71 (2015) doi: 10.1515/amsc-2015-0005

11. K. Krawiec, Z. Pilecki, Numeryczna symulacja procesu zapadliskowego $w$ warunkach geologicznych $i$ górniczych niecki bytomskiej na terenie pogórniczym ptytkiej eksploatacji złóż rud metali (Numerical simulation of the sinkhole process in geological and mining conditions of the Bytom basin in the post-mining area of shallow mining of metal ore deposits) Technika Poszukiwań Geologicznych 1, 47-62 (2012)

12. Z. Fajklewicz, Znaczenie badań geofizycznych $w$ procesie przywracania wartości uzytkowych terenom naruszonym dokonana eksploatacja górnicza (Significance of geophysical research in the process of restoring utility values to sites violated by mining) Mat. Konf.: Warsztaty Górnicze, Wyd. IGSMiE PAN, Kraków, 45-86 (2001)

13. H. Marcak, Z. Pilecki, Some Geophysical and Geomechanical Remarks on Recognition Sinkhole Processes in Post-Mining Areas, Proc. 12 ${ }^{\text {th }}$ European Meeting of Environmental and Engineering Geophysics, 4-6 September 2006, Helsinki, Finland (2006)

14. Z. Pilecki, The role of geophysical methods in the estimation of sinkhole threat in the post-mining areas of shallow exploitation in the Upper Silesian Coal Basin, Poland, Gospod. Surowcami Min. 24, 3/1, 27-40 (2008)

15. Z. Fajklewicz, Origin of the anomalies of gravity and its vertical gradient over cavities in brittle rock, Geophys. Prospect. 34, 6, 1233-1254 (1986) 
16. G. C. Colley, The detection of caves by gravity measurements, Geophys. Prospect. 11, 1-10 (1963)

17. D. Lyness, The gravimetric detection of mining subsidence, Geophys. Prospect. 33, 567$576(1985)$

18. J. C. Cook, Seismic mapping of underground cavities using reflection amplitudes, Geophysics 30, 4, 527-538 (1965)

19. R. Neumann, La gravimétrie de haute précision-application aux recherches de cavities, Geophys. Prospect. 15, 1, 1-2 (1967)

20. E. Pilecka, D. Szwarkowski, E3S Web Conf. 24, 01006 (2017) doi: $10.1051 / \mathrm{e} 3$ sconf/20172401006

21. A. Sałustowicz, Zarys mechaniki górotworu (Outline of rock mass mechanics) Wyd. Śląsk, Katowice (1968) (in Polish)

22. Z. Pilecki, A. Kotyrba, Problematyka rozpoznania deformacji nieciagtych dla potrzeb projektowania konstrukcji drogowych na terenie plytkiej eksploatacji rud metali (Problems of recognizing discontinuous deformations for the purpose of designing road structures in shallow metal ore mining) Prace Naukowe GIG III, 379-392 (2007) 